Saudi Journal of Humanities and Social Sciences

Abbreviated Key Title: Saudi J Humanities Soc Sci

ISSN 2415-6256 (Print) | ISSN 2415-6248 (Online)

Scholars Middle East Publishers, Dubai, United Arab Emirates

Journal homepage: https://saudijournals.com

Original Research Article

\title{
Identity Conflict and Development Challenge in Nigeria's Fourth Republic, 2011-2020
}

Ogele Eziho Promise ${ }^{1 *}$

${ }^{1}$ Department of Political Science, Rivers State University, Nkpolu Orowurukwo, Port Harcourt, Nigeria

DOI: 1 10.36348/sjhss.2021.v06i03.001 $\quad$ | Received: 24.02.2021 | Accepted: 08.03.2021 | Published: 16.03 .2021

*Corresponding author: Ogele Eziho Promise

\section{Abstract}

The paper examined the nexus between identity-based conflict and the development challenge in Nigeria's Fourth Republic. The study was informed by the increasing disjointed loyal relationship between the citizens and the nation, which has adversely impacted on the country's socio-political and economic advancement. Using the descriptiveanalytical method, the study adopted triangulation methods of data gathering techniques. 3,600 copies of a questionnaire titled 'identity conflict and development challenge in Nigeria's Fourth Republic', which was administered in the six geopolitical zones of the country using a combination of the random and purposive sampling methods to select the study areas. Two hypotheses were tested using the statistical tool of simple percentages and the Spearman Rank Correlation Coefficient at 5\% significance level. The study adopted the Political Economy paradigm as its theoretical construct. The study unravelled a significant linkage between identity-based conflict and Nigeria's development challenge. Second, the study unravelled that identity conflicts have adversely impacted on the socio-economic development since Nigeria's Fourth Republic. The study, therefore, amongst others recommends national dialogue, that will facilitate peaceful coexistence in Nigeria.

Keywords: Ethnicity, conflict, development, identity, nation.

Copyright (C) 2021 The Author(s): This is an open-access article distributed under the terms of the Creative Commons Attribution 4.0 International License (CC BY-NC 4.0) which permits unrestricted use, distribution, and reproduction in any medium for non-commercial use provided the original author and source are credited.

\section{INTRODUCTION}

Conflict is an essential aspect of a plural society. It is inevitable under the condition of interethnic competition for scarce valuable resources, especially in societies where inequality is accepted and wealth is greatly esteemed. The fear of being undermined at the lowest level of the inter-ethnic ladder has resulted in an identity struggle and destructive socioeconomic competition, which have become a threat to development in Nigeria." Ramsbotham, Woodhouse and Miall [1] argued that "conflicts themselves often change character over time, are interpreted in different ways by the conflict parties, and can always be captured and manipulated by unscrupulous power-brokers who subsequently justify their depredations by appeal to principle."

Nigeria is a heterogeneous country with over 250 ethnic nationalities, amalgamated in 1914 by the British Government. Under the colonial rule, the union was confronted with ethnic related conflict before she attained political independence in 1960. The first conflict was identity induced Kano riot of 1953, which led to the death of 21 southerners and 15 northerners, and about 241 people injured [2]. The second was the post-independence Nigerian civil war, which was fought along ethnic lines leading to the estimated deaths of over 2 million persons, and the destruction of property worth millions of dollars.

Having considered the adverse impact of ethnic conflict on national development, the federal government decided to set up several agencies, commissions and institutional frameworks to facilitate national integration and obtain desired development. Sadly, these efforts have not yielded the desired results. It is evidence that Nigeria's development challenge has defied all the development efforts of successive governments over the years.

At present, the majority of the citizens live on their meagre resources. They are compelled to provide for themselves the necessities such as drinking water, electricity, roads and sometimes security - tasks which are the primary responsibility of the government. This, to an extent, shows a failure of the state in its contractual obligation to the people. This apparent 
'breach of contract' by the state creates a disarticulation in the people's perception of the state as a platform for the realization of their aspirations, their relationship with and loyalty to the nation. As Locke, in his 'Two Treatises of Government' 1690 puts that:

... when the State negates its social responsibility (i.e. Protection of life and properties, ensuring person's wellbeing and justice) or the King becomes a tyrant and acts against the interests of the people, then people have the right, if not an outright obligation, to resist the authority. Thus a socially irresponsible and unresponsive State or leadership, which scuttles good governance, simply creates the atmosphere for social disobedience, instability, up-rising and revolving [3].

Giving the above, the country is presently confronted with loyalty crisis. This is demonstrated in the weakening of the bond between the nation and its citizens, citizens' low sense of ownership of the state, increase in group nationalism, a significant drop in the people's commitment to the cause of the state, among others. These further seem to have an impact on the nation's economy, security and social life.

At the dawn of the 21st century, several ethnic violent groups like the Indigenous People of Biafra (IPOB), the Movement for the Emancipation of the Niger Delta (MEND), the Movement for the Survival of the Ogoni People (MOSOP), Oodua People's Congress (OPC), Arewa People's Congress (APC), the SouthSouth Peoples Assembly (SSPA), among others, began to emerge. Olurode \& Anifowose [4] in his work noted that the emergence of ethnic militias..., have created a new kind of ethnic conflict in the country." The clamour for self-determination or the review of the terms of their engagement with the nation lends credence to the people's seeming disillusionment in the nation as a platform for the achievement of their socioeconomic aspirations. The occasional growing defiant resistance to or even confrontation with state authority, even sovereignty or sometimes attack on national economic assets or symbols speak of a loss of faith in the nation. An instance of loyalty crisis against the Nigerian state was demonstrated by the Movement for the Emancipation of the Niger Delta (MEND) in the few years. Ajayi [5] wrote that:

Militant youths in the Niger Delta, Monday initiated another deadly attack on the country's oil facility in that area, blowing up a military houseboat and an oil pipeline in continuation of their armed campaign against the Federal Government. The militants who are holding nine foreign hostages vowed to prevent Royal Dutch Shell from using the damaged forcados tanker loading platform, which accounts for 15 Percent of Nigerian exports and threatened an even more devastating series of attack on the whole region (p. 2).

Against this background, the study interrogates the nexus between identity conflict and development threat in Nigeria. It sought how the identity-based conflict in Nigeria has adversely impacted the nation's quest for development since the emergence of the Fourth Republic. The study is structured into three parts. First, the paper looks at the introduction; concepts of identity, conflict and development; theoretical framework, amalgamation and the emergence of identity crisis in Nigeria; as well as their interconnectivity. The second part focuses on methodology; data presentation, tests of hypotheses and discussion of findings. The third part captures conclusion/recommendations made as part to promote national cohesion and maintain stability in Nigeria.

\section{CONCEPTUAL REVIEW \\ The concept of conflict}

The quest for identity within a defined territory has sometimes led to low intensify local conflicts globally. Conflicts are as old as mankind. Hence, "there is no single, agreed-upon definition of what constitutes... conflict" [6]. Various scholars or experts have defined the concept based on events at a given time or period. Within the human realm, a conflict occurs between two or more individuals or groups, or within or between large social organizations or nationstates. The term conflict epitomizes disharmony, hostility or antagonism in a relationship, which could emerge due to incompatibility of goals being pursued or incongruity of the ways and means adopted in pursuing the preferred goal. Picciotto [7] asserts that "conflict is inherent to the human condition. It arises when individuals or groups hold divergent interests and values." Conflict is a global phenomenon. Zartman [8] maintained that "conflict is universal and inherent in social activity, and deadlock and violence-escalated are frequent, instinctive possibilities, despite their cost, pains and ineffectiveness. For Zartman, conflict simply as "an incompatibility of positions, a static situation when mutually exclusive views are present... an effort to prevail in a contest between those incompatible positions" [8]. Mitchell [9] supported this view when he asserted that:

Conflict is inevitable because it can originate in individual and group reactions to situations of scarce resources, division of functions within society and differentiation of power and the resultant competition for limited supplies of goods, status, valued roles and power-as-an-end itself (p. 17).

Similarly, Folger, Poole, and Stutman [10] defined the conflict as "the interaction of interdependent people who perceive incompatibility and the possibility of interference from others as a result of this incompatibility." One of the contemporary conflict theorists, Johan Galtung argued that "human conflicts are largely due to a real or perceived incompatibility, or contradiction, between conflicting parties' attitudes, behaviours, interests, needs, positions, and or values" [11]. In describing the nature of the conflict, Galtung buttressed the phenomenon as a: 
Dynamic processes in which structure, attitude, and behaviour are constantly changing and influencing one another. As the dynamic develops, it becomes a manifest conflict formation as parties' interests clash or the relationship they are in becoming oppressive. Conflict parties, then organize around this structure, to pursue their interest. They develop hostile attitudes and conflicted behaviour" [1].

Conflicts grow, intensify, and widening by drawing in other interested parties. However, "in some situations, a conflict may threaten to escalate and draw in additional parties. Actors who fear such escalation and expansion may seek to reduce the conflict to avoid becoming involved in hostilities" [8]. The phenomenon implies that deepening and spreading or generating secondary conflicts within the main parties and outside sympathizers may intensify the conflict. Hence, many scholars had questioned the existence of various forms of conflicts based on different definitions of the phenomenon. Also, some scholars have challenged the 'conflict typology'. In conflict studies, many typologies do exist "and the criteria employed not only vary but are often mutually incompatible, some differences in terms of conflict parties, others in terms of conflict issues, other in terms of conflict causes" [1].

Conflicts are triggered by motives. Plato examined the "conflict of motives in the individual and concludes that we cannot, without contradiction, assume the existence of fewer than three types of motive or impulse in the mind. First, there is a reason, the faculty that calculates and decides; second, there is desire or appetite, in the sense of bare physical and instinctive craving. There is also a third type of motive, covering,... such characteristics as pugnacity, enterprise, ambition, indignation, which are often found in conflict within unthinkable impulse" [12].

\section{Identity conflict}

Ramsbotham, Woodhouse and Miall [1] define identity conflict as conflicts that "involves the relative status of communities or communal groups, however, defined, about the state." Depending upon the kind of the group and the contextual situation, this includes struggles for access, for autonomy, for the session or control [13]. Snegovaya [14] in his work titled "National Identity Crises Threaten World Order" explains that national identity is the feeling of commonality among a people and their commitment to defend the nation which represents the platform upon which such commonalties are better projected and protected. Identity is created by the coming together of people from the same (homogeneous group), socioeconomic background. It is built on values that appeal to the past, and also normal to establish an identity based on the myth of common ancestry. Hence, Ekekwe [15] puts that:

Each person (in the state) has an idea of who she or he is, and the identity she (or he) chooses invariably includes multiple of factors that are important to her (or him): the home town where the person was born, the school she (or he) attended, the culture, region or state of origin or the country. These factors of identity may appear in the concentric or layered form and the importance of each may vary from situation to situation (p. 2).

In the case of many nations, the basis for National identity ranging from ethnic, tribal regions, religions, and class peculiarities. No nation is 'pure'. This is because each nation possesses a basis for the definition of its people - the foundation for its identity such as common ancestry, common values, and common national symbols, among others. The existence of national symbols, through which all segments of the society can be identified, represents the basis for their identity [16].

Regardless, those values, symbols or commonalities constitute a cord that generates the 'we' feeling among members of society. This inoculates in the citizens, the spirit of prior loyalty to the nation -a resolve to always commit to the cause of the nation and possibly pay the supreme price if situations demand. Gellner in Bechhofer \& McCrone [17] noted that:

Citizenship invokes in people, the spirit of nationalism, and that nationalism is the taken-for-granted ideology which binds us to the state, or, as he would have it, the nation. People fight and die for the nation - with an alarming willingness (p. 5).

This is borne out of the belief that it is in the preservation of the nation that the interests of the citizens are guaranteed. In attempting to establish a national identity, the preamble of the Nigerian constitution removed the values that constitute the cord that bind the diverse peoples of the country together. We the people of the federal republic of Nigeria, having firmly and solemnly resolved, to live in unity and harmony as one indivisible and indissoluble sovereign the promotion of inter African solidarity, world peace, international cooperation and understanding. And to provide for a constitution to promote good government and welfare of all persons in our country, on the principles of freedom, equality and justice, and to consolidate the unity of our people.

The challenge is limited to Nigerians. Osaghae [18] noted that:

The identity crisis is not simply about identity per se as, for example, being Ghanaian. Both within and outside his country, a Ghanaian is more likely to, without prodding, identify himself as such. The problem is mainly in the injunctions that follow this identity; prior loyalty and commitment to the state rather than the ethnic, religious, regional or even, class Communities.' The crisis has to do with the dilemma as to which unit of identity enjoys the citizen's prior loyalty (p.4). 
Furthermore, Elebeke [19] in Osimen, Balogun and Adenegan [20] explains that an identity conflict occurs when one either loses track of who he is or feels dissatisfied with his identity and wants to change or restructure his life. This feeling of discontent with one's identity and the desire to restructure it presents a picture of an internal dilemma within a person, which ultimately finds an outward expression in their perception of, and relationship with the object of identity (the state).

However, Osaghae narrows the national identity crisis down to a loyalty crisis between the citizens and the state. Furthermore, Osaghae [18] argued that:

These identity-entities compete for the individual's loyalty in usually, zero-sum terms, and the individual often has to choose an identity. The consequence of this is that the State which, to the extent of its being sovereign within the given territory, is supposed to be the claimant of every citizen's identity and loyalty, loses its monopoly and has to compete with partial and particularist entities like ethnic and religious communities, regions, provinces, classes and so on which also lay claims, to the individual's loyalty [18].

\section{Development}

Local conflicts emanating from national identity have resulted in development challenges in Nigeria. According to Thirlwall [21], is perhaps that of the development of the world community with particular reference to the poor nations. From the end of the Second World War in 1945, interest in the eradication of extreme poverty from among the entire human race has gained prominence. In discussing development, many definitions, perspectives and approaches arise. Amartya Sen, who defines development from the angle of the existence and expansion of people's 'entitlements' and the capabilities that these entitlements generate. By entitlements, Sen means.

The set of alternative commodity bundles that a person can command in a society using the totality of rights and opportunities that he or she faces', measured in terms of availability of employment opportunities, welfare provisions of the state, the spatial distribution of resources, opportunities and power relations in society [21].

Nevertheless, the concept of development in Nigeria can be better understood the degree of undevelopment experienced in the country. Nurkse [22], underdevelopment is a product of the existence of the vicious circle of poverty. These vicious circles possess the capacity to trap the underdeveloped societies in an unending loop of economic incapacitation. In his words:

It implies a circular constellation of forces tending to act and react upon one another in such a way as to keep a poor country in a state of poverty [22].
Underdevelopment from the lenses of the modernization school is defined in terms of explaining the factors responsible for the economic gap between rich and poor nations. Naanen [23] argued that the persistence of Underdevelopment, where such exists, does so due to resistance to the diffusion of cultural elements from the developed to the underdeveloped countries. Nna [24] noted that the underdeveloped societies are characteristically governed by such variables as the predominance of kinship relations, communal loyalty, descriptive status and nonmaximising economic behaviour, where social ends take precedence over accumulation.

\section{Theoretical Framework}

The study adopted the Political Economy Paradigm. The Political Economy framework represents those theories built around of economic, sociological, political, psychological and geographical elements within the context of historical change [25]. It looks at the problems of the society in a cross-disciplinary, holistic approach; from a standpoint of social relations and historical evolution. The political economy examines the complex interplay of socio-economic forces in defining and redefining the sub and superstructures of any given society. Ake [26] opines that the approach gives primacy to man's material conditions of existence as a key determinant of other facets of his life. He notes that:

Economic need is man's most fundamental need. Unless he can meet this need, he cannot exist in the first place. He must eat before he can do anything else - exhibit patriotism, acquire education, seek space exploration and be willing to pay the supreme price in the defence of his society [27].

Indeed, while the political machinery sets the economic development agenda for the members of the society; their material conditions of existence, as well as their perception of the society, influence their response and role in the society and by extension to define the politics and the development of the society. Central to this framework is the analysis of class relations. Nna [24] succinctly puts it that:

Political Economy focuses attention on not only the production and management of society's material wealth, but also its distribution among the various segments or classes and conflicts which arise from these processes.

The political economy approach employs dialectical materialism as a method of analysis. It explores the ever-present and on-going class conflicts historically. It viewed that development and underdevelopment as products of the same historical process such that the development of one leads to the underdevelopment of the other. It is therefore clear from this framework that man's, and by extension, the society's development at any given time is a product of class interaction, defined in terms of the appropriation 
of societal values as well as the synthesis that emerges as a resolution of the thesis/ antithesis clash over time.

Linking this approach to this study explains the irony of the majority of Nigerians living under conditions of economic deprivation in a country naturally endowed in the world, while a minority lives in inexplicable opulence. This helps us highlight the reality of the class conflict which is rooted in the struggle for the appropriation of surplus value. Ekekwe [28] notes that:

Class relationships involve conflict and opposition. They are dynamic relationships. There may indeed appear to be complementary aspects of class relationships, as in the capitalist mode of production, the coexistence of the bourgeoisie and the proletariat. It is precisely in this seemingly complementary association between them that the elements of conflict and opposition are embedded. Conflict and opposition are rooted in the struggle for the appropriation of surplus value. This class conflict may not always be openly expressed and it may not always take very clear forms (p. 7).

Second, it helps us explain how these class contradictions, representing the thesis-antithesis structure, is generating a conflict as manifested in the identity conflict, which has the potentials of evolving a new social order of a more equitable distribution of the commonwealth.

The third was the roles of the traditional elite in the perpetual Balkanization of the country, without them the state's policy of indirect rule could not have worked. The other comprised educated persons without any links with the traditional rule. This goes further to explain that, some groups were to become professionals and private entrepreneurs. This set the stage for the emergence of the petty bourgeois class. From among the fractions and strata of the petty bourgeoisie came its dominant element: the political leaders. Political leaders upon gaining political power became petty bourgeoisie who turned that power into a means for accumulation of both wealth and capital.

\section{Nigeria's amalgamation and the emergence of identity conflict}

Until 1900, the landmass is known today as Nigeria existed as several independent and sometimes, with linguistic and cultural differences. The North, the Hausa/Fulani operated a feudal system of government, which continued after the conquest of the Fulani. It is imperative to note that the feature of the feudal system of government was that at first, the power was centralized and later on was delegated. The Emirs were subjects of the Sultan of Sokoto, who was the chief of the Emirs. Islamic laws gave specific powers to the emirs. Traditions and conventions also stated the boundaries of their power and thus made the feudal system of government works [29].
The West can be said to be culturally homogenous who operated relatively a modern form of government that is organized in cities and towns. For instance, in rural areas, the government was based on the clan. The Oni of lfe is the King. He ruled the territory through his chiefs. The chiefs collected tribute from the people and divided it with Oni of Ife. In lfe, Ogboni, the local court, acted as the next higher tribunal where cases were referred. The final court of appeal comprised of Oni himself, members of the Ogboni, and the town chiefs [29].

The East was relatively heterogeneous. The Ibo race constitutes the majority of the population; there was a strong government of egalitarianism in practice. Except in the river area, the people were elaborately organized in small semi-autonomous communities like the clan, the village, and the family. In the river area such as Calabar, Opobo, Bonny and Onitsha, Kingship was common. Kings in such areas like King Jojo of Opobo or Obi of Onitsha had political powers comparable to that of Oni of lfe. Their governments were democratic [29].

The British Government maintained a Consul in Lagos. In 1861, the British Government obtained the Cession of the Island in Lagos with the sole aim of putting an end to the oversea slave traffic. However, in the following years, the West African settlements were contemplated, and the extension of responsibilities with the interior was vetoed. It was not until the Scramble for Africa followed the Berlin Act of 1885 that steps were taken to secure the coastline of Lagos to the Cameroons and establish a claim to the hinterland as a British Sphere of influence [30].

In January $1^{\text {st }}, 1900$, the government of the Northern and Southern Nigeria were created. In 1906, the first step of amalgamation was realized in the South. Southern Nigeria and Lagos became one administration under the title of the Colony and Protectorate of Southern Nigeria. The material prosperity of the south increased with astonishing rapidity. The liquor dutiesincreased from 3s-in 1901 to 3s.6d. In 1905, the revenue stood at 5s.6d gallon in 1912, and afforded ever-increasing revenue, without any diminution in the quantity imported. They yielded a sum of $£ 1,138,000$ in 1913 [30]. However, the North was largely supported and depended on the annual grant from the Imperial government. The North was barely able to balance its budget with the most parsimonious economy, and was starved of the necessary staffers, and unable to find funds to house its officers properly. Its energies were concentrated upon the development of the Native Administration and the revenue resulting from direct taxation [30].

On January $1^{\text {st }}, 1914$, the former Governments of Southern and Northern Nigeria were formally amalgamated. According to Lugard [30]: 
Amalgamation was not a mere political, geographical, or more, especially a financial expression, but a means whereby each part of Nigeria should be raised to the level of the highest plane attained by any particular part. It was regarded that each of the administrations (North and South) had much to learn from each other. The North- a younger Government was capable of improvement in its development organization, and backward both in the development of its mineral resources and the facilities (such as roads) required for the purpose. The south required a better organization for its Native Administration and of its judicial system (p.8).

Though, the amalgamation was confronted with several hiccups, such as divergent in policy and methods that existed in the former administration of Southern and Northern Nigeria. It was clear at the beginning that the new amalgamated state will be confronted in with the challenges of national cohesion. The reasons deduced by Frederick Lugard were that Southern Nigeria had been longer under British rule. Its wealth in oleaginous produce had attracted large numbers of trader, chiefly British and German, whose influence had naturally been in the direction of the material development of roads, waterways, and trade. While the Northern Nigeria administered by Royal Niger Company has no practical link to the Native Administration, and their official of the chartered company were unable to go far from the banks of the Niger and Benue.

Sir Huge Clifford (1920-31) had described Nigeria as a collection of independent native states, separated from one another... by great distances, by differences of history and traditions and by ethnological, racial, tribal, political, social and religious barriers" Nigerian Council Debate, 1922.

Not too long, the amalgamation of 1914 became a clog in the wheel of progress. In 1948, Sir Arthur Richard regrettably said "it is only the accident of British suzerainty which had made Nigeria one country. It is still far from being one country or one nation socially or even economical... socially and politically there are deep differences between the major tribal groups" [31]. Akin to it was a statement credited to late chief Obafemi Awolowo his book titled, Path to Nigeria freedom which was published in 1947 that: Nigeria is not a nation; it is a mere geographical expression. There are no "Nigerians" in the same sense as there are "English" or "Welsh" or "French". The word Nigeria is merely a distinctive appellation to distinguish those who live within the boundaries of Nigeria from those who do not [31].

Given the above, the identity acrimony has been entrenched in Nigeria before her political independence in 1960. For instance, in 1953, when Chief Anthony Enahoro moved the motion for political independence, which led to a protest by the Northern political elites, later metamorphosed to ethnically related riots in the City of Kano. The riot led to the destruction of lives and properties, particularly at Sabon Gari. Ogele [32] noted that:

...Lugard [did not only] succeed in bringing them together, but also created room for ethnic conflicts that have remained in existence for 67 years since after Kano riot in 1953. Despite all the rhetoric of the successive governments on national integration, the ethnic consciousness has eaten deep into the fabrics of Nigeria to the extent that every national issue is debated or view along ethnic lines. Hence, Nigeria has witnessed several conflicts emanating from ethnic strives. For instance, the Nigerian [civil] war was fought along the ethnic lines leading to the estimated deaths of over 2 million persons, and the destruction of property worth billions of dollars.

\section{METHODOLOGY}

The study adopted a descriptive research design as its research plan. The selection of the population for this study was done to reflect the nation's political configuration. The study adopted triangulation methods of data gathering techniques. Each state was selected from each of the six geopolitical zones of the country. One Local Government Area was selected in each state as our study area. This gave us a total of 6 study areas with a population of $1,729,811$, National Population Census, 2006. The breakdown includes Abia state (Osisoma Ngwa LGA- 219,632), Rivers State (Obio/Akpor LGA -464,789), Oyo State (Ibadan North LGA-308, 119), Adamawa State (Yola South LGA196,197), Plateau State (Mangu LGA- 294,931); and Jigawa State (Dutshe LGA - 246,143). The random sampling method was adopted for the selection of the states, while the purposive sampling method was used in the final selection of the final study areas. A total of 3,600 copies of the questionnaire was administered. Respondents were selected from the 25 years and above age bracket. This was to ensure that respondents would have been at least 10 years old as of 2011-2020. The study employed statistical tools such as frequencies and simple percentages in its analysis, while the Spearman rank correlation coefficient test statistic was used to analyses the hypothesis at the 5\% level of significance.

\section{Data Presentation and Analysis}

The study examined the data derived from the questionnaire. The analysis was in two phases. The first was the bio-data (demographic) of the respondents were analysed; second, the data under investigation were analysed in the tables. The results of the tests for the reliability are presented as follows: 


\section{Descriptive Statistics}

Table-1: Respondents' Demographic Data Analysis -1

\begin{tabular}{|c|c|c|c|}
\hline 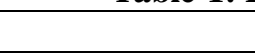 & Frequency & Percent & Cumulative Percent \\
\hline \multicolumn{4}{|l|}{ Gender } \\
\hline Male & 2340 & 65 & 65 \\
\hline Female & 1260 & 35 & 100.00 \\
\hline Total & 3600 & 100.0 & \\
\hline \multicolumn{4}{|l|}{ Age } \\
\hline $25-35$ yrs. & 1688 & 46.8 & 46.8 \\
\hline $36-46$ yrs. & 1104 & 30.6 & 77.4 \\
\hline 47-61 yrs. & 538 & 14.9 & 92.3 \\
\hline 62 yrs. \& Above & 270 & 7.5 & 100 \\
\hline Total & 3600 & 100.0 & \\
\hline \multicolumn{4}{|c|}{ Educational Level } \\
\hline Primary & 725 & 20.1 & 20.1 \\
\hline Secondary & 984 & 27.3 & 47.4 \\
\hline Technical & 522 & 14.5 & 61 \\
\hline Tertiary & 1369 & 38.1 & 100 \\
\hline Total & 3600 & 100.0 & \\
\hline
\end{tabular}

The above table indicates that 2,340 respondents were male, while 1,260 respondents were female, corresponding to $65 \%$ and $35 \%$ respectively. 1,688 respondents were aged $25-35$ years corresponding to $46.8 \%$, while $1,104,538$ and 270 respondents were aged 36-46, 47-61 and 62 years \& above respectively. The table further shows that 725 respondents had primary educational qualification which corresponds to 20,1\%, while 984, 522 and 1,369 respondents had secondary, technical, and tertiary educational qualification respectively corresponding to $27.3 \%$, $14.5 \%$ and $38.1 \%$ ) respectively.

Test of Hypotheses

Hypothesis 1

$\mathrm{H}_{01}$ : There is no significant correlation between Identity-based conflict and the development of Nigeria.

Table-2: Spearman Correlation Test Result for Research Hypothesis 1

\begin{tabular}{|l|l|l|}
\hline & Identity conflict & Development \\
\hline Correlation Coefficient & 1.000 & $-.686 "$ \\
\hline Identity Conflict & & \\
\hline $\begin{array}{l}\text { Sig. (2-tailed) } \\
\text { Crisis (NIC) }\end{array}$ & & .001 \\
\hline $\mathrm{N}$ & 3600 & 3600 \\
\hline Spearman's rho & & 1.000 \\
\hline $\begin{array}{l}\text { Correlation } \\
\text { Coefficient }\end{array}$ & -.686 & \\
\hline $\begin{array}{l}\text { National Development } \\
\text { Sig. (2-tailed) }\end{array}$ & .001 & 3600 \\
\hline $\mathrm{N}$ & 3600 & \\
\hline \multicolumn{1}{|l|}{$* *$ Correlation is significant at the 0.01 level (2-tailed). }
\end{tabular}

The Spearman correlation test above indicates that there is a negative significant correlation between identity-based conflict and the Nigeria's development with a correlation coefficient of -0.68 and a p-value $(0.001)<5 \%$ significance level. The result further indicates that as Identity-based conflict increases, there is a decrease in the development of Nigeria. Hence, the null hypothesis that there is no significant correlation between Identity-based conflicts and the development of Nigeria is rejected.

$\mathrm{HO}_{2}$. There is no significant adverse impact of identity-based conflict on development in Nigeria. 
Table-3: Analysis of the nexus between Identity conflicts and development

\begin{tabular}{|c|c|c|c|c|c|}
\hline \multirow[b]{2}{*}{$\mathbf{S} / \mathbf{N}$} & \multirow[b]{2}{*}{ Item } & \multicolumn{3}{|c|}{$\begin{array}{l}\text { Identity Based Conflict and } \\
\text { Development/Underdevelopment }\end{array}$} & \multirow[t]{2}{*}{ Total } \\
\hline & & A & D & DK & \\
\hline 1 & $\begin{array}{l}\text { The low sense of ownership of the country among the } \\
\text { people is responsible for their lack of care for public } \\
\text { property and poor response to public service }\end{array}$ & $\begin{array}{l}1892 \\
52.5 \%\end{array}$ & $\begin{array}{l}1148 \\
31.9 \%\end{array}$ & $\begin{array}{l}560 \\
15.6 \%\end{array}$ & $\begin{array}{l}3600 \\
100 \%\end{array}$ \\
\hline 2 & $\begin{array}{l}\text { The brain drain among Nigerian professionals in search of } \\
\text { socio-economic fulfilment abroad increases the shortage } \\
\text { of professional manpower in the nation's public } \\
\text { institutions and poor health care delivery }\end{array}$ & $\begin{array}{l}1989 \\
55.2 \%\end{array}$ & $\begin{array}{l}1101 \\
30.6 \%\end{array}$ & $\begin{array}{l}510 \\
14.2 \%\end{array}$ & $\begin{array}{l}3600 \\
100 \%\end{array}$ \\
\hline 3 & $\begin{array}{l}\text { Sabotage of public economic assets and pipeline } \\
\text { vandalism leads to a huge loss of revenue and disrupts the } \\
\text { gas flow and hinders effective power generation }\end{array}$ & $\begin{array}{l}2104 \\
58.4 \%\end{array}$ & $\begin{array}{l}1080 \\
30 \%\end{array}$ & $\begin{array}{l}416 \\
11.6 \%\end{array}$ & $\begin{array}{l}3600 \\
100 \%\end{array}$ \\
\hline 4 & $\begin{array}{l}\text { Diversion of public funds for personal use deprives the } \\
\text { nation a sizeable chunk of funds for infrastructural } \\
\text { development. }\end{array}$ & $\begin{array}{l}1969 \\
54.7 \%\end{array}$ & $\begin{array}{l}977 \\
27.1 \%\end{array}$ & $\begin{array}{l}654 \\
18.2 \%\end{array}$ & $\begin{array}{l}3600 \\
100 \%\end{array}$ \\
\hline 5 & $\begin{array}{l}\text { Display of disloyalty to the state increases the rate of } \\
\text { crime and insecurity which hinder economic activities }\end{array}$ & $\begin{array}{l}1832 \\
50.9 \%\end{array}$ & $\begin{array}{l}1403 \\
39.0 \%\end{array}$ & $\begin{array}{l}365 \\
10.1 \%\end{array}$ & $\begin{array}{l}3600 \\
100 \%\end{array}$ \\
\hline 6 & $\begin{array}{l}\text { The incessant identity-based agitations and clamour for } \\
\text { the restructuring of the basis of the nation's existence } \\
\text { weakens national cohesion and economic development }\end{array}$ & $\begin{array}{l}2223 \\
61.8 \%\end{array}$ & $\begin{array}{l}549 \\
15.2 \%\end{array}$ & $\begin{array}{ll}828 \\
23.0 \%\end{array}$ & $\begin{array}{l}3600 \\
100 \%\end{array}$ \\
\hline 7 & $\begin{array}{l}\text { Hiding or investing illegally acquired public funds abroad } \\
\text { deprives the nation of development funds }\end{array}$ & $\begin{array}{l}2157 \\
59.9 \%\end{array}$ & $\begin{array}{l}968 \\
26.9 \%\end{array}$ & $\begin{array}{l}475 \\
13.2 \%\end{array}$ & $\begin{array}{l}3600 \\
100 \%\end{array}$ \\
\hline & Grand Total & $\begin{array}{l}14166 \\
56.2 \%\end{array}$ & $\begin{array}{l}7226 \\
28.75\end{array}$ & $\begin{array}{l}3808 \\
15.1 \%\end{array}$ & $\begin{array}{l}25200 \\
100 \%\end{array}$ \\
\hline
\end{tabular}

The table above reveals that the respondents have the feeling low sense of ownership to Nigerian as a project. This feeling was responsible for their lack of care for public property and poor response to the public service $(52.5 \%)$. The brain drain experienced Nigerian professionals in search of socio-economic fulfilment beyond the border of Nigeria have led to the acute shortage of professional manpower in the nation's public institutions and poor health care delivery $(55.2 \%)$. The sabotage of public economic assets disrupts the gas flow and hinders effective power generation $(58.4 \%)$. The diversion of public funds for personal use deprives the nation a sizeable chunk of funds for infrastructural development (54.7). The display of disloyalty to the state increases the rate of crime and insecurity which hinder economic activities (50.9\%). The incessant identity-based agitations and clamour for the restructuring of the basis of the nation's existence weaken national cohesion (61.8\%). The hiding or investing illegally acquired public funds abroad deprives the nation of development funds $(59.9 \%)$. The table indicates that to a significant extent, the national identity conflict (NIC) has contributed to the underdevelopment of Nigeria.

\section{DISCUSSION OF FINDINGS}

It is the common thread that weaves via the views of many scholars on the causes of the identical based conflicts is that it is a natural consequence of the failure of the state in its contractual obligations to its citizens. That is, the inability of the state to justify its relevance in the material conditions of the majority of its people. One of the pillars of development is security. The former Secretary of Defence of the United State of America, Robert S McNamara asserted that:

In a modernizing society, security means development... Security is development. Without development, there can be no security. A developing nation that does not develop simply cannot remain "secure." It cannot remain secure for the intractable reason that its citizenry cannot shed its human nature. Without internal development of at least a minimal degree, order and stability are simply not possible. They are not possible because human nature cannot be frustrated beyond intrinsic limits. It reacts because it must [33].

Osaghae argued that identity- based conflict is occasioned by the dislocation of the mutually beneficial bond expected to exist between the state and her citizens. Osaghae [18] pointed out that:

The alienation of the people, which started with the establishment of the colonial state....is worsened in the post-colonial period by the ineptitude of African governments to make good, the hopes and expectations of independence as well as their never-ending promises of a life more abundant. The people are sick and tired; poor and hungry... there is a frustration which makes some believe that the state is "irrelevant". This has an ominous effect on national identity because people cannot be expected to be loyal to a state that frustrates them. 
Obvious in the above is the fact that the people's sense of national pride and their confidence in the state is crushed when the latter fails in her contractual obligation of providing the conditions and amenities considered necessary for the citizens to access their basic needs of food, healthcare, security and socio-economic infrastructure. This has ominous implications for the people's perception of the state as a reliable platform through which their collective aspirations can be met. It also has such implications in the people's sense of loyalty and commitment to the state.

From our findings, the majority of the masses, from their meagre resources are compelled to provide for themselves, such necessities as water, power, and roads, among others, which are ordinarily, the primary responsibility of the state. Indeed, it is unbelievable for an average Nigerian to contemplate building a living house without making private provisions for a borehole facility for his water needs and of course, a power generating set for the supply of electricity, among others. This clear inability of the state to sufficiently justify its relevance in its relationship with the citizens tends to strip it of its moral authority to demand citizens' overarching loyalty.

Living in this state of deprivation, in a country richly endowed with abundant natural resources portrays the state as an insensitive entity before the people. It is thus seen as one which does not necessarily exist for the achievement of the greatest good of the greatest number. Consequently, the people are compelled to seek alternative platforms (other identity entities) through which their economic needs, which is man's greatest needs can be met. This sets the stage for the loyalty crisis in the system. Nnoli captured this succinctly when he observed that:

The apparent withdrawal of the government from the realm of employment and social welfare amenities also heightened the importance and significance of these associations for the individual. They became the only institution within which he could meaningfully expect to solve some of his most pressing problems...

With the increasing greater salience of the union than the colonial state for the satisfaction of the socio-economic needs of the individual, the member gave these unions his loyalty at the expense of the state. This transfer of loyalty was reinforced by the rewards accruing to him from the activities of the communal association [34].

This is in tandem with the view of Locke [35] in his 'Two Treatise of Government'. For him, the state's negligence of responsibility constitutes the primary cause of a loyalty crisis. In his words:

... when the State negates from its social responsibility (i.e. Protection of life and properties, ensuring person's well-being and justice) or the King becomes a tyrant and acts against the interests of the people, then people have the right, if not an outright obligation, to resist the authority. Thus a socially irresponsible and unresponsive State or leadership, which scuttles good governance, simply creates the atmosphere for social disobedience, instability, up-rising and revolution [3].

It is therefore not surprising that the nation has, in recent years, experienced a disturbing level of loyalty crisis as manifested by the surge in identity and resource-based agitations. The rise of groups like the Indigenous People of Biafra (IPOB), the Movement for the Actualization of the Sovereign State of Biafra (MASSOB), the Movement for the Emancipation of the Niger Delta (MEND), the Movement for the Survival of the Ogoni People (MOSOP), Oodua People's Congress (OPC), Arewa People's Congress (APC), among others, and their clamour for either self-determination or resource control lend credence to the people's seeming disillusionment in the nation as a platform for the achievement of their socio-economic aspirations. Most of these groups' objectives are captured in such documents as the Ogoni Bill of Rights published in 1990, the Kaiama Declaration in 1998, among others. Having lost faith in the system, citizens tend to seek refuge in other identity platforms, which they believe, rightly or wrongly, hold the promise of filling the void the failure of the state has created. The high-handedness of a government in its relationship with its citizens may trigger citizens' resistance to its authority and by extension, a loyalty crisis.

As a mono-economy, the centrality of the oil pipeline grid to Nigeria's economic survival. The first case of pipeline vandalism in Nigeria occurred in 1995, a year that marked the height of state repression and brutal response to the clamour for a more inclusive socio- economic order by the Movement for the Survival of the Ogoni People (MOSOB), the human right activist group of the Ogoni people, on whose soil, a reasonable percentage of Nigerian oil resource is drilled. The Managing Director, Pipeline Products Marketing Company (PPMC) - a subsidiary of the Nigerian National Petroleum Corporation (NNPC), Haruna Momoh, in a 2013 pipeline vandalisation meeting hosted by the Lagos Chamber of Commerce and Industry (LCCI) revealed that:

1995 was the year that the act of vandalism crept into our operations. The activities of vandals, over the years, have continued unabated, have become more sophisticated, well equipped and fully armed, and now siphon crude oil using barges and "Cotonou" boats through inserting/concealed valves from the PPMC pipelines supplying crude oil to the refineries and petroleum products to the Depots. Before then, all we had were occasional rupture / failures of the pipes depending [36]. 
From the few cases of pipeline vandalism in 1995, the crisis grew to about 34,747 cases of vandalism between 1999 and 2014 [37]. The impact of these on the nation's resources and development drive can only be imagined. For Olufayo, a major factor responsible for the national identity conflict is ethnicity. This position also finds a level of validity within the Nigerian experience. Public positions in Nigeria guarantee access to the 'national cake'. Its allocation, therefore, influences the balance of economic power among the nation's social configurations. Such allocations thus become a tool in the hands of the operators of the state policy machinery to either empower or weaken the material capacities of citizens both as individuals and as groups.

Our findings revealed that it is this tendency towards the exclusion of those 'others' that drive the feeling of a loss of ownership of the state. Beyond increasing the intensity of the struggle for the access to power, it engenders a loss of faith in the system, sapping, in the process, citizens' prior loyalty to the state and the expected commitment to make sacrifices for its well being or even the willingness to pay the supreme price for it when necessary. Our findings reveal that people tend to project separateness when their wellbeing, particularly, the economy becomes threatened. Such mobilizations affect loyalty to the state most when such a threat assumes an official dimension, which is if it emanates from or is perpetuated by those saddled with the responsibility of managing state affairs. In other words, identity, diversity becomes a precursor to a national identity crisis when managers of state affairs use their positions to further the interests of certain identities to the exclusion of the 'others'.

The Niger Delta struggles in Nigeria for instance, never assumed such a violent dimension until the 1990s, when the economic repression of the region got to such unacceptable heights that even state might be directed against the people's legitimate demand for fairer socio-economic treatment. Nigeria is largely a mono-economy. Its economy is oil-dependent. The centrality of oil resources in the sustenance of her economy is not contestable as it contributes over $85 \%$ of the nation's foreign exchange earnings and constitutes her major export commodity [38]. Beyond its export value, it also holds an essential domestic value as virtually all sectors of the economy depends on it. To ensure efficient distribution of the resource around the country, an intricate network of pipelines was designed across it. Nigeria has a total pipeline grid of 5,001 kilometres. This consists of 4,315 kilometres of multi-product pipelines and 666 kilometres of crude oil pipeline [39]. These form a network that interconnects the nation's 22 petroleum storage depots, four refineries (Port Harcourt - 2, Warri - 1 and Kaduna - 1), the offshore terminals at Bonny and Escravos, and the Jetties at Alas cove, Calabar, Okrika and Warri [40].
Pipelines are therefore an important economic asset through which the nation's economic wheels are lubricated. Any compromise to it constitutes a major threat to the Nigerian economy. In recent times, these oil pipelines have become the target for the expression of frustration by certain identity groups who feel their interest in the nation is not guaranteed and therefore demand greater autonomy or self-assertion as a means of achieving their collective aspirations as a people.

From our findings, in a report on a deadly attack on oil facilities owned by shall Petroleum Development Company (SPDC) and the Nigerian Agip Oil Company (NAOC) in Delta and Bayelsa State, the Movement for the Emancipation of the Niger Delta (MEND), a militant body, whose professed aim is to fight for the sociopolitical and economic emancipation of the oil-rich Niger-Delta region of the country, openly and shockingly claimed responsibility. In its statement, the group's spokesman, Gbomo Jomo admitted that:

At about 300hrs today, Thursday, March 27, 2014, Scuba divers from The Movement for the Emancipation of the Niger Delta (MEND) revisited the Shell Forcados Sub-C pipeline in the western Delta which we had sabotaged earlier on Saturday, March 01, 2014... We were successful in causing further damage to the ongoing repair works, inflicting the heaviest toll ever on the oil industry since the commencement of 'Hurrican Exodus' MEND also takes responsibility for the Thursday, March 20, 2014 attack on the Agip crude oil and gas pipeline in Ikarama Oil field located in Bayelsa State [41].

The NNPC Annual Statistical Bulletin, 2014 states that the nation lost 59.597 billion Naira worth of crude oil and other petroleum products in 3,732 breakages within the year. The Corporation explains that this consists of 355,690 metric tonnes of petroleum products valued at 44.75 billion Naira, 1.08 million barrels of crude oil valued at 14,847 billion Naira. A further breakdown shows that 3,700 of the breakages as a result of vandalism while 32 cases were due to system deterioration [37].

Our findings revealed that between 1999 and 2014 , It was reported that a total of 37,747 pipelines were vandalized (NNPC - 2014 Annual statistical Bulletin). According to the Group Managing Director (GMD), Dr Joseph Dawha, 34, 047 cases of these cases were recorded in the different parts of the country between 1999 and 2013 while 3,700 took place in 2014 . The report also stated that about 1.3 million metric tonnes of crude oil were said to have been lost in the illicit act between 2009 and 2012 [42]. It is estimated that the nation loses about $\$ 14 \mathrm{bn}$ to pipeline vandalism annually. Reporting the outcome of leading research on the cost of vandalism in the Niger Delta, John Vidal posits that:

Pipeline vandalism in the Niger delta costs the state and oil companies $\$ 14$ bn (£9.3bn) a year and devastated up 
to 52,000 hectares of land in 2014 , according to new estimates by a leading Nigerian research and development group. The scale of pipeline vandalism which sees infrastructure tapped to steal crude oil - has now reached epidemic proportions... The thefts range from small-scale pilfering to industrial-scale theft coordinated and collaborated with the Nigerian military, corrupt corporate executives and community leaders [43].

Beyond the monetary value of the stolen or wasted oil, a colossal amount of money is also spent on pipeline repairs. The Managing Director of the Nigerian Gas Company, Mr Dafe Sejebor, disclosed that the minimum cost for the repair of a damaged gas pipeline in the Niger Delta region is about N160 million [44]. A total of about 37, 747 cases of vandalism between 1999 and 2014, the revenue loss to the nation can only be imagined. Furthermore, the wave of militancy also "choked the supply of gas to local power plants, thus hobbling Nigeria's power grid. Electricity generation in Nigeria has declined from about 4,800 megawatts in August 2015 to 1,000 megawatts in May 2016" [45]. This deprives the nation enormous development funds and amplifies the nexus between the identity conflict and underdevelopment. However, other factors, such as crime, poor policing of the lines, poor maintenance culture, among others contribute to the incidents of pipeline breaks [43]. The disarticulation of the loyal relationship between the citizens and the state, arising from the feeling of group exclusion, remains the greatest driving factor behind these sabotages.

It is estimated that the Biafra struggle has cost the economy of the South-East of Nigeria over 20 billion Naira in the last one month of protests during which shops were closed in the major economic cities of Aba and Onitsha and economic activities were disrupted [46]. Various instructions given by the leader of IPOB, Mazi Nnamdi Kanu, especially the members of IPOB in South-East states on sit-at-home directive led to huge economic waste.

Beyond financial and human resource loss, these agitations sometimes escalate inter-ethnic and religious rivalry, especially when people from other ethnic groups lose their lives or when religious institutions are targeted. This creates the possibility of reprisal attacks in those other parts of the country, which further snaps the already drained inter-ethnic bond and depletes the development potentials of the nation.

As demonstrated by our field survey, if given the opportunity to ply their trade outside the country, $51.5 \%$ of Nigerians would leave the country rather than stay back, make sacrifices and contribute to its development. 2014 report from the office of the Secretary to the Government of the Federation (SGF) reveals that there are about 3.25 million Nigeria's living in America today. The report continues:

$\ldots$ of this number, there are over 115,000 Nigerian medical professionals, 744,000 IT professionals, 87,000 pharmacists, 49,500 engineers and over 250,000 legal, financial, real estate and related business professionals [47].

The implication of such a monumental loss of skilled manpower in an economy desperate for such services can only be imagined. This explains, for instance, the acute shortage of medical personnel in our hospitals and health centres and of course the poor health service delivery in the nation.

\section{Concluding Remarks}

The study has shown that national identitybased conflict is a salient impediment to the development in Nigeria. It is silent because it resides in the psychological realm and conditions the people's relationship with the "others' within the system as well as their collective relationship or commitment to the nation. The people's perception of the state influences the direction of their loyalty and conditions their response and commitment to its wellbeing and development. Many Nigerian's have a very low sense of ownership of the country. The institutional arrangements, management and allocation of opportunities in the system, rather than facilitates their chances of attainment of the 'good life', became a source of frustration. The consistent inability of the state to provide the people with opportunities to fulfil their socio-economic aspirations negates the very values that constitute the basis of the nation's identity as enshrined in the preamble of Nigeria's constitution. Though, the ethnic character of the crisis cannot be overruled, that is because it provides an alternative identity platform for the people's expression of their disaffection against state repression, the root of the national identity based conflict in Nigeria is more of an economic than ethnic.

\section{In light of the above, the following recommendations are put forward:}

1. The study recommends a national dialogue on the corporate peaceful existence of the Nigerian identity-entities. In other word, the outcome of the 2014 National Conference should be implemented without delay.

2. The policy of distributive justice should be vigorously pursued. This will ensure a more equitable distribution of resources and opportunities among the different segments and classes of the society.

3. As a heterogeneous society, the basis for Nigeria's national identity as enshrined in the preamble of the constitution should be revisited and redefined.

4. The principle of 'Citizenship', which foresters the 'we' feeling should be emphasised over the 'indigeneship' which promotes 'separateness'. 
Nigerians should be free to live, work and settle in any part of the country of their choice without discrimination.

Declaration of Conflicting Interests: The author(s) declared no potential conflicts of interest with respect to the research, authorship, and/or publication of this article.

Funding: The author(s) received no financial support for the research and/or authorship of this article.

\section{REFERENCE}

1. Ramsbotham, O., Woodhouse, T., \& Miall, H. (2005). Contemporary Conflict Resolution: The prevention, management and transformation of deadly conflicts. Second Edition. Cambridge. Polity Press.

2. James, S. D. (2001). Constitutional Development in Nigeria: An Overview. In Jason Osia, O. (ed) Intoduction to Political Science: A Nigerian Perspective. Port Harcourt. Ulamba Pub.

3. Hamza, A. Y. (2007). Leadership Role and Good Governance in Nigeria. Zaria, Department of Public Administration, Ahmadu Bello University, Zaria. http:/www.imim-ng.org/downloads/Dr Hamza's Article.doc.

4. Olurode, L., \& Anifowose, R. (2004). Issues in Nigeria's General Elections. Lagos. John West Publications Limited and Rebonik Publication Limited.

5. Ajayi, F. (2006). Crisis in the Delta Lagos, The Daily Sun, p. 2.

6. Szayna, T. S., O’Mahony, A., Kavanagh, J., Watts, S., Frederick, B., Norlen, T. C., \& Voorhies, P. (2017). Conflict Trends and Conflict Drivers: An Empirical Assessment of Historical Conflict Patterns and Future Conflict Projections. Santa Monica, California. RAND Corporation Pub.

7. Picciotto, R. (2011). The Political Economy of Conflict. In Erin McCandless and Tony Karbo (eds) Peace, Conflict, and Development In Africa: A Reader. Switzerland. University for Peace Pub.

8. Zartman, W. I. (2008). Negotiation and Conflict Management: Essays on theory and practice. London. Routledge Pub.

9. Mitchell, C. R. (1998). The Structure of International Conflict. New York. St Martins Press.

10. Folger, J. P., Poole, M. S., \& Stutman, R. K. (2005). Working through conflict: strategies for relationships, groups, and organizations. New York: Longman Pub.

11. Barash, D. P., \& Webel, C. P. (2014). Peace and Conflict Studies. Third Edition. Los Angeles. Sage Pub.

12. Lee, H. D. P. (1955). Plato: The Republic Translated with an Introduction by Desmond Lee. London. Penguin Books.
13. Gurr, T. (1995). Transforming ethnopolitical conflicts: exist, autonomy or access? In Rupesinghe, eds, 53-78.

14. Snegovaya, M. (2015). National Identity Crises Threaten World Order. Moscow, The Moscow Times, http://www.themoscowtimes.com/opinion/article/ national-identity-crises-threaten-worldorder/520918.html

15. Ekekwe, E. N. (2011). in Ekekwe E. N., Erne C. N., Ukoha U, Mathew O. (eds) Identity Politics in Nigeria. Port Harcourt, University of Port Harcourt Press.

16. Obshchestva, T. I. M. A. (2014). Antsyferov, N. Dusha Peterburga. Petersburg. Brokgauz-Efron, 1922. The Shape of Apocalypse in Modern Russian Fiction, 277.

17. Bechhofer, F. \& McCrone, D. (2009). National Identity, Nationalism and Constitutional Change. Palgrave, Macmillan Pub.

18. Osaghae, E. (1998). The Crisis of national Identity: Clearing the Conceptual Underbush. The Journal of Modern African Studies.

19. Elebeke, E. (2010). Identify crisis: Who really are Nigerians. Central Database) Export Highlight Nation's Identity Management Crisis at CTO May, 12, 2010.

20. Osimen, G. U, Balogun, A., \& Adenegan, T. S. (2013). Ethnicity and Identity Crisis: Challenge to National Integration in Nigeria IOSR Journal of Humanities and Social Sciences. 16(4).

21. Thirwall, A. P. (2008). Development and Economic Growth in Desai, V., \& Potter, R. B. (eds) (2008). The companion to Development Studies, second edition, London, Flodder Education.

22. Nurkse, R. L. (2007). 'Problem of Capital Formation in Underdeveloped Countries' in Jhingan M. (ed) The Economics of Development and Planning. Delhi, Vrenda Publications (P) ETD.

23. Naanen, B. (1984). Theories of Underdevelopment: How Relevant to Africa, Pan African Social Science Review (PASSR) No.1

24. Nna, J. (2002). Contemporary Political Analysis: an Introduction. New Owerri, Springfield Publishers Limited.

25. Okowa, W. (1996). How the Tropics Underdeveloped the Negro, A Questioning Theory of Development. Port Harcourt, Paragraphics.

26. Ake, C. (1981). A Political Economy of Africa. England. Longman Pub.

27. Ake, C. (1981). A Political Economy of Africa Lagos, Longman Nigeria Pic.

28. Ekekwe, E. N. (1986). Class and State in Nigeria. Lagos, Longman Group Limited.

29. Utuk, E. I. (1975). Britain's Colonial Administrations and Developments, 1861-1960: An Analysis of Britain's Colonial Administrations and Developments in Nigeria. A thesis submitted 
in partial fulfilment of the requirements for the degree of MASTER OF SCIENCE IN TEACHING in HISTORY .Portland State University.

30. Lugard, F. D. (1919).Nigeria. Report by Sir F. D. Lugard on the amalgamation of northern and southern Nigeria, and administration, 1912-1919. London. House of Common Parlimentary Paper Online.

31. Ekpu, R. (2017). Geographical expression: So what? The Guardian, August 15. Retrieved from: https:/guardian.ng/opinion/geographicalexpression-so-what/

32. Ogele, E. P. (2020). Elitism, Election, and Governance in Nigeria's Fourth Republic. A Study of Rivers State from 2003-2019. Journal of Law and Global Policy. Vol 5 No 1. www.iiardpub.org

33. McNamara, R. S. (1966). Security in the Contemporary World. American Society of Newspaper Editors. Montreal, Canada, May 18th. Retrieved from: http://www.oldcolo.com/McNamara/mcnamara.txt

34. Nnoli, O. (1978). Ethnic Politics in Nigeria. Enugu. Fourth Dimension Publishers.

35. Locke, M. (1960). The cuticle and wax secretion in Calpodes ethlius (Lepidoptera, Hesperidae). Journal of Cell Science, 3(55), 333338.

36. Momoh, H. (2013). Petroleum Pipeline Vandalisation Cost Nigeria N164b in 4 years. $\mathrm{http} /$ marineandpetrleum. com/petroleum-pipelinevandlisation-costs-nigeria-n 163b-4-years/

37. Dunn, E. (2015). NNPC: Read How Much Nigeria Loses to Pipeline Vandalism http://www.naij.com/477013-nnpc-read-howmuch-nigeria-loses-to-pipeline-vandalism.htm
38. Odumosu, D. (2011). How Really Underdeveloped Is Nigeria? Arizona, USA, Nigeria world.

39. Okoli, A. C., \& Orinya, S. (2013). Oil Pipeline Vandalism and Nigeria's National Security. USA, Global Journal of Human \& Social Science. 13(5)

40. Onuoha, F. (2007). Poverty, Pipeline Vandalization, Explosion and Human Security. Integrating Disaster Management into Poverty Education in Nigeria \&quot;http://www.google.com.

41. Niyi, N. (2014). MEND Claims Responsibility for Attack on Shell Agip Facilities. Information Nigeria, www.infonnationnigeria2014/03/mendcaliins-responsibility-for-attack-on-shell-agipfacilities.html/

42. Nwachukwu, C. A. (2014). Nigeria Records 34, 049 Cases of Pipeline Breaks. This Day live, http://mgafrica.com.

43. Vidal, J. (2015). Niger Delta Oil Pipeline Vandalism Estimated to Cost \$14bn a Year. The Guardian.

http://www.theguardian.com/environment/2015/no v/10/niger-delta-oil-pipelinevandalism estimated-to-cost-14bn-a-year.

44. Eboh, M. (2015). Nigeria Loses N8bn to Gas Pipeline Vandalism. Lagos. Vanguard News.

45. Onuoha, F. (2016). The Resurgence of Militancy in Nigeria's Oil-Rich Niger Delta and the Dangers of Militarisation. Al Jazeera Center for Studies. Retrieved from: http://studies.aljazeera.net/en

46. Alaribe, U., Okonkwo, N., Nkwopara, C., \& Igata, F. (2015). Traders Count Losses as IPOB shuts Markets. Lagos, The Vanguard. http://www.vanguardngr.com/2015

47. Anyim P. A (2014). Nigeria Diaspora Day. Office of the Secretary to the Government of the Federation http://nigeriadiasporaday.org/about _diaspora_day/ 